\title{
TAN-999 AND TAN-1030A, NEW INDOLOCARBAZOLE ALKALOIDS WITH MACROPHAGE-ACTIVATING PROPERTIES
}

\author{
Seitchi Tanida, Masayuki Takizawa, Toshiyuki Takahashi, \\ Shigetoshi Tsubotani and Setsuo Harada
}

\begin{abstract}
Microbiology Research Laboratories, Research \& Development Division, Takeda Chemical Industries Ltd., 2-17-85 Juso-honmachi, Yodogawa-ku, Osaka 532, Japan
\end{abstract}

(Received for publication May 22, 1989)

\begin{abstract}
Two new indolocarbazole alkaloids, TAN-999 and TAN-1030A, were isolated from culture broths of Nocardiopsis dassonvillei C-71425 and Streptomyces sp. C-71799, respectively. Their structures were elucidated on the basis of their reactions, spectroscopic analyses and in particular, comparison of spectral data with that of staurosporine.

These metabolites induced spreading of a murine macrophage cell line, $\mathrm{Mm} 1$. They also augmented the phagocytic activity, Fcy receptor expression and $\beta$-glucuronidase activity of murine macrophage cell lines, $\mathrm{Mm} 1$ and J774A. 1 . When proteose-peptone elicited peritoneal macrophages from mice were incubated with these metabolites for 2 days, the phagocytosis-dependent respiratory burst of these cells was enhanced. Similar enhancement was also observed when the peritoneal macrophages in mice were modulated by intraperitoneal administration of these metabolites. These results reveal that TAN-999 and TAN-1030A can activate macrophage functions in mice.
\end{abstract}

Macrophages act as regulatory and effector cells in the host defense system. They are phagocytic and are potentially destructive to invading microorganisms and neoplastic cells. ${ }^{1,2)}$ Thus, the activation of macrophage function by natural or synthetic substances is expected to be applicable for therapy of microbial infection and cancer.

In our search for immunomodulators of microbial origin, three metabolites having macrophage-activating properties were found in culture broths of two actinomycetes isolated from soil samples. One is a metabolite of Nocardiopsis dassonvillei $\mathrm{C}-71425$ and is designated TAN-999. The other two, TAN-1030A and staurosporine, ${ }^{3,4}$ are metabolites of Streptomyces sp. C-71799. TAN-999 and TAN-1030A are new alkaloids belonging to the staurosporine family (Fig. 1).

Fig. 1. Structures of TAN-999 and TAN-1030A.

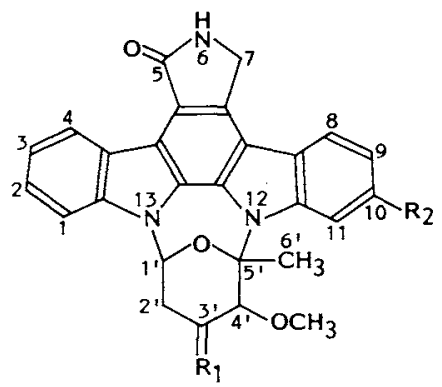

$\begin{array}{lll}\text { TAN-999 (1) } & \mathrm{R}_{1}=\mathrm{NHCH}_{3}, \mathrm{H} & \mathrm{R}_{2}=\mathrm{OCH}_{3} \\ \text { TAN-1030A (2) } & \mathrm{R}_{1}=\mathrm{NOH} & \mathrm{R}_{2}=\mathrm{H} \\ \text { Staurosporine } & \mathrm{R}_{1}=\mathrm{NHCH}_{3}, \mathrm{H} & \mathrm{R}_{2}=\mathrm{H}\end{array}$

\section{Materials and Methods}

\section{Taxonomic Studies}

Culture characterization was carried out following the International Streptomyces Project procedure. ${ }^{5)}$ The color recorded for the mature culture was described according to the Color Harmony Manual. ${ }^{6}$ Cell analysis was performed by the method of HASEGAWA et al. ${ }^{7)}$ Scanning electron microscopy was conducted by the method of TANIDA et al. ${ }^{8)}$

Fermentation

A loopful of strain C-71425 or C-71799 grown on mature slant culture was inoculated into a 2-liter 
Sakaguchi flask containing $500 \mathrm{ml}$ of a sterile seed medium. The flask was shaken on a reciprocal shaker at $28^{\circ} \mathrm{C}$ for 48 hours. The seed medium consisted of glucose $2 \%$, corn steep liquor $1 \%$, soybean flour $1 \%$, peptone $0.5 \%, \mathrm{NaCl} 0.3 \%$ and $\mathrm{CaCO}_{3} 0.5 \%$. Five hundred $\mathrm{ml}$ of the seed culture were transferred to a 50 -liter fermenter containing 30 liters of the same medium, and the fermentation was carried out at $28^{\circ} \mathrm{C}$ for 48 hours with aeration of 30 liters/minute and agitation of $280 \mathrm{rpm}$. Six liters of the seed culture were transferred to a 200 -liter fermenter containing 120 liters of a production medium consisting of glucose $0.5 \%$, dextrin $5 \%$, soybean flour $3.5 \%$ and $\mathrm{CaCO}_{3} 0.7 \%$. The fermentation was carried out at $28^{\circ} \mathrm{C}$ with aeration of 120 liters/minute and agitation of $120 \mathrm{rpm}$.

Isolation of T.AN-999 (1)

The culture broth (110 liters) was adjusted to $\mathrm{pH} 9$, EtOAc (110 liters) was added, and the mixture was stirred for 1 hour. After filtration using Hyflo-Super Cel, the aqueous layer was discarded. The extract was washed with water (25 liters) and concentrated. The residue was chromatographed on a column of silica gel $(50 \mathrm{~g})$ eluting with EtOAc - $\mathrm{MeOH}(9: 1)$. The active fractions detected by morphological changes in $\mathrm{Mm} 1$ were left standing at $4^{\circ} \mathrm{C}$ to afford pale yellow crystals of $1(1.1 \mathrm{~g})$.

Isolation of TAN-1030A (2)

The culture broth (35 liters) was filtered using Hyflo-Super Cel and the mycelium was extracted with acetone (15 liters). The extract was concentrated to remove the acetone, and the concentrate ( 6 liters) was cxtracted with EtOAc ( 3 liters $\times 2)$ after addition of $\mathrm{NaCl}(500 \mathrm{~g})$. The extract was washed with water (1.5 liters) and concentrated. The residue was chromatographed on a column of silica gel $(125 \mathrm{~g})$ eluting with EtOAc-MeOH $(9: 1)$. The active fractions were concentrated and again chromatographed on silica gel $(50 \mathrm{~g})$, this time eluting with EtOAc. The active fractions were concentrated to give a crude powder of 2 $(1.07 \mathrm{~g})$. The crude powder was purified by silica gel column chromatography $(50 \mathrm{~g})$ eluting with $\mathrm{CHCl}_{3}-\mathrm{MeOH}(49: 1)$. The bio-active fractions were concentrated and crystallized from $\mathrm{CHCl}_{3}-\mathrm{MeOH}$ to give colorless crystals of $2(110 \mathrm{mg})$.

\section{Hydrogenation of 2 to 3}

Compound $2(72 \mathrm{mg})$ in $60 \%$ aqueous acetic acid was hydrogenated over Pt-black $(25 \mathrm{mg})$ at room temperature. The catalyst was filtered off and the filtrate was evaporated. EtOAc $(30 \mathrm{ml})$ was added to the residue, and the mixture was extracted with $0.05 \mathrm{~N} \mathrm{HCl}(25 \mathrm{ml} \times 4)$. The aqueous layers were combined, adjusted to $\mathrm{pH} 9.4$ and extracted with EtOAc $(50 \mathrm{ml} \times 3)$. The extract was washed with a saturated aqueous solution of $\mathrm{NaCl}$, dried over $\mathrm{Na}_{2} \mathrm{SO}_{4}$ and concentrated. Adding $\mathrm{Et}_{2} \mathrm{O}$ to the residue gave a powder of 3 (53 mg).

$[\alpha]_{\mathrm{D}}+90.4^{\circ}\left(c 0.28, \mathrm{CHCl}_{3}\right) ;{ }^{1} \mathrm{H}$ NMR $\left(\mathrm{CDCl}_{3}\right) \delta 9.44(1 \mathrm{H}, \mathrm{d}, J=8.2 \mathrm{~Hz}), 7.97(1 \mathrm{H}, \mathrm{d}, J=8.6 \mathrm{~Hz})$, $7.89(1 \mathrm{H}, \mathrm{d}, J=7.3 \mathrm{~Hz}), 7.50(1 \mathrm{H}, \mathrm{t}), 7.44(1 \mathrm{H}, \mathrm{t}), 7.38(1 \mathrm{H}, \mathrm{t}), 7.33(1 \mathrm{H}, \mathrm{t}), 7.29(1 \mathrm{H}, \mathrm{d}, J=7.9 \mathrm{~Hz})$, $6.58(1 \mathrm{H}, \mathrm{d}, J=4.0 \mathrm{~Hz}), 6.33(1 \mathrm{H}, \mathrm{s}), 5.02(2 \mathrm{H}, \mathrm{ABq}), 3.75(2 \mathrm{H}, \mathrm{m}), 3.46(3 \mathrm{H}, \mathrm{s}), 2.60(2 \mathrm{H}, \mathrm{m}), 2.33(3 \mathrm{H}$, s): Secondary ion (SI)-MS $m / z 453(\mathrm{M}+\mathrm{H})^{+}$

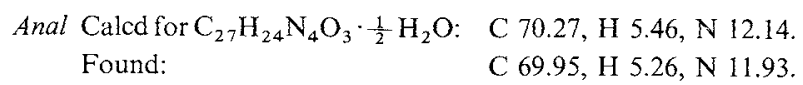

Acetylation of 3 to 4

$\mathrm{Ac}_{2} \mathrm{O}(0.3 \mathrm{ml})$ was added to a solution of $3(30 \mathrm{mg})$ in pyridine $(0.6 \mathrm{ml})$, and the mixture was left standing at room temperature for 3 hours. The reaction mixture was diluted with EtOAc $(20 \mathrm{ml})$ and washed with $0.05 \mathrm{~N} \mathrm{HCl}(20 \mathrm{ml} \times 2)$ and a saturated aqueous solution of $\mathrm{NaCl}$ successively. The solution was evaporated to dryness and adding $\mathrm{Et}_{2} \mathrm{O}$ to the residue gave a powder of 4 ( $28 \mathrm{mg}$ ).

${ }^{1} \mathrm{H}$ NMR $\left(\mathrm{CDCl}_{3}\right) \delta 9.40(1 \mathrm{H}, \mathrm{d}, J=7.9 \mathrm{~Hz}), 7.97(1 \mathrm{H}, \mathrm{d}, J=9.0 \mathrm{~Hz}), 7.94(1 \mathrm{H}, \mathrm{d}, J=8.5 \mathrm{~Hz})$, $7.51(1 \mathrm{H}, \mathrm{t}), 7.48(1 \mathrm{H}, \mathrm{t}), 7.39(2 \mathrm{H}, \mathrm{t}), 7.28(1 \mathrm{H}, \mathrm{d}, J=9.4 \mathrm{~Hz}), 6.71(1 \mathrm{H}, \mathrm{s}), 6.61(1 \mathrm{H}, \mathrm{d}, J=5.2 \mathrm{~Hz}), 5.16$ $(1 \mathrm{H}, \mathrm{d}, J=6.2 \mathrm{~Hz}), 5.04(2 \mathrm{H}, \mathrm{s}, \mathrm{like}), 4.60(1 \mathrm{H}, \mathrm{m}), 3.91(1 \mathrm{H}, \mathrm{d}, J=4.4 \mathrm{~Hz}), 3.40(3 \mathrm{H}, \mathrm{s}), 3.09(1 \mathrm{H}, \mathrm{dd}$, $J=3.1$ and $15.0 \mathrm{~Hz}), 2.53(1 \mathrm{H}, \mathrm{m}), 2.39(3 \mathrm{H}, \mathrm{s}), 0.81(3 \mathrm{H}, \mathrm{s})$ : Electron impact (EI)-MS $m / z 494 \mathrm{M}^{+}$.

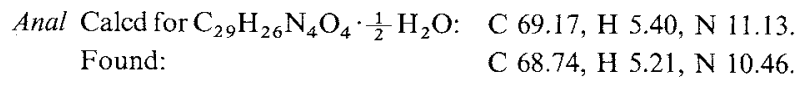


Murine Macrophage Cell Lines and Media

The cell line, $\mathrm{Mm}^{\left.{ }^{9}\right)}$ was kindly donated by Dr. MAEDA, Chest Disease Research Institute, University of Kyoto. Mm 1 was usually cultured with GIT medium. ${ }^{10)}$ To determine the expression of Fc $\gamma$ receptors, Mm 1 was cultured with EAGLE's minimum essential medium (MEM) containing $10 \%$ fetal calf serum (FCS). The cell line, J774A.1 ${ }^{11,12)}$ was purchased from the American Type Culture Collection (ATCC). J774A. 1 was cultured with RPMI-1640 medium containing $10 \% \mathrm{FCS}$. They were incubated $37^{\circ} \mathrm{C}$ in an atmosphere of $5 \% \mathrm{CO}_{2}$ in air. Growth of these cells was measured by the 3-(4,5-dimethylthiazol-2-yl)-2,5diphenyltetrazolium bromide (MTT) reduction assay. ${ }^{13)}$

\section{Scanning Electron Microscopy}

$\mathrm{Mm} 1$ cells were cultured with each metabolite on coverslips for 2 days. Then, monolayers of the cells on the coverslips were fixed with $2 \%$ glutaraldehyde in phosphate-buffered saline (PBS; $\mathrm{Ca}^{++}$and $\mathrm{Mg}^{++}$ free) for 1 hour and then in $1 \%$ osmium tetroxide in water for 1 hour. The fixed $\mathrm{Mm} 1$ cells were dehydrated in graded ethanol, critical-point dried in liquid $\mathrm{CO}_{2}$, and coated with gold. The specimen was then viewed with a scanning electron microscope (Hitachi model S-570).

\section{Assay for Phagocytosis}

Mm 1 or J774A.1 cells, $2.0 \times 10^{5}$ cells, were cultured in a plastic dish ( $3.5 \mathrm{~cm}$ i.d., Corning Co., U.S.A.) with each metabolite for 2 days. Then, $1.0 \times 10^{7}$ fluorescein isothiocyanate (FITC)-labeled latex particles ( $1.74 \mu \mathrm{m}$ i.d., Polyscience Inc., U.S.A.) were added to the culture. After incubating 45 minutes, the cells were washed 3 times with HANKS' balanced salt solution (HBSS). The number of cells which ingested more than 10 particles was counted as the number of phagocytic cells under an inverted fluorescence microscope (Olympus IMT-2; magnification, $\times 400$ ).

\section{Assay for Fey Receptor}

Fcy receptors on the surface of $\mathrm{Mm} 1$ or J774A.1 cells were detected by the EA rosette assay. ${ }^{14)}$ Sheep red blood cells (SRBC) coated with anti-SRBC IgG (EA $\gamma$ complexes) were prepared by incubating 4 volumes of SRBC in PBS at $5.0 \times 10^{8} / \mathrm{ml}$ with one volume of a $1 / 10,000$ dilution of the purified IgG fraction of rabbit anti-SRBC at $37^{\circ} \mathrm{C}$ for 30 minutes. $\mathrm{Mm} 1$ or J774A.1 was cultured with each metabolite for 2 days and was adjusted to $2.0 \times 10^{7} \mathrm{cells} / \mathrm{ml}$, and the suspension was incubated with the EAy complexes $\left(2.0 \times 10^{7} / \mathrm{ml}\right)$ at $0^{\circ} \mathrm{C}$ for 90 minutes. Cells in the microscopic fields with five or more adherent complexes were counted as Fe $\gamma$-receptor mediated rosettes.

\section{Assay for $\beta$-Glucuronidase Activity}

$\beta$-Glucuronidase activity was determined by hydrolysis of phenolphthalein-mono- $\beta$-glucuronic acid at pH 4.5. ${ }^{15)}$ Two-day cultures of $\mathrm{Mm} 1\left(1.0 \times 10^{6}\right)$ in a tissue culture dish $(10 \mathrm{~cm}$ i.d., Corning Co., U.S.A.) with each metabolite were washed with HBSS, and the adherent cells were lysed with Triton $\mathrm{X}-100$. The cell lysate was centrifuged at $2,500 \times g$ for 10 minutes, and the supernatant was used as the enzyme source. The amount of protein in the supernatant was estimated with the Bio-Rad Protein Assay Kit.

\section{Macrophage Experiments in Mice}

Female C57BL/6 CrSlc inbred mice 7 weeks of age were purchased from Shizuoka Laboratory Animal Center, Japan. One $\mathrm{ml}$ of $10 \%$ Proteose-peptone (PP) in saline was injected ip. The peritoneal exudate cells (PECs) were harvested 96 hours after injection by rinsing the peritoneal cavity with cold EAGLE's MEM containing $10 \%$ FCS. The PEC suspension was transferred to a borosilicate glass culture tube $\left(6 \times 50 \mathrm{~mm}\right.$, Kimble, U.S.A.) and incubated for 2 hours at $37^{\circ} \mathrm{C}$ in an atmosphere of $5 \% \mathrm{CO}_{2}$ in air. The PECs were then washed twice with pre-warmed medium to remove non-adherent cells $\left(2.0 \times 10^{5}\right.$ adherent cells/tube). The adherent macrophages were incubated with each metabolite for 2 days under $5 \% \mathrm{CO}_{2}$. The cells were then washed twice with HBSS.

In vivo modulation of peritoneal macrophages with these metabolites was carried out as follows. One $\mathrm{ml}$ of $10 \% \mathrm{PP}$ in saline was administered ip and each metabolite was injected ip 72 hours later. Twentyfour hours after the second injection, PECs were harvested. Three mice were used for each dose of the metabolites, and the PECs from the mice receiving the same dose were mixed together. The PEC suspension 
was transferred to a borosilicate glass culture tube and incubated for 1 hour under $5 \% \mathrm{CO}_{2}$. The PECs were washed twice with pre-warmed medium to remove non-adherent cells $\left(1 \times 10^{5}\right.$ adherent cells/tube $)$.

\section{Respiratory Burst of Peritoneal Macrophages}

The phagocytosis-dependent respiratory burst in mouse peritoneal macrophages was evaluated by measuring the chemiluminescence response using luminol. The standard reaction mixture contained the peritoneal macrophages described above, $5 \times 10^{-7} \mathrm{M}$ luminol and $1 \mathrm{mg} / \mathrm{ml}$ opsonized zymosan (OPZ) in a total volume of $100 \mu \mathrm{l}$ in a glass culture tube. The reaction was initiated by the addition of the OPZ, and the chemiluminescence was measured for 8 minutes with a luminometer (Picolite model 6106, Packard, U.S.A.)

\section{Chemicals}

EAGLE's MEM, RPMI-1640 medium, HBSS and FCS were obtained from Whittaker M. A. Bioproducts, Inc., U.S.A. GIT medium was purchased from Nippon Seiyaku Co., Japan. The serum was inactivated by heating at $56^{\circ} \mathrm{C}$ for 30 minutes prior to use. The SRBC and anti-SRBC antibody were purchased from Cooper Biomedical, Inc., U.S.A. Other materials and their sources were as follows: Phenolphthalein-mono- $\beta$-glucuronic acid (Sigma Chemical Co., U.S.A.); luminol (Wako Chemical Co., Japan); OPZ (ZAP, Packard Instrument Co. Inc., U.S.A.); PP (Difco Labs., U.S.A.).

\section{Results}

\section{Taxonomy of the Producing Organism}

Strain C-71425 was isolated from a soil sample collected in Tottori Prefecture, Japan. Cell analysis of the strain showed the presence of meso-diaminopimelic acid. Galactose and ribose were present but madurose, xylose, galactose and arabinose were not present in whole-cell hydrolysate. Accordingly, the cell wall type of strain C-71425 is chemotype III/C. Each spore chain of this strain consists of about 20 spores. The spores are cylindrical and have a smooth surface (Plate 1A). The vegetative mycelia of the strain grown in liquid medium divide into rod-shaped, irregular and branching fragments. Sporangia and flagellated spores are not observed. These characteristics of strain C-71425 indicate that it belongs to the genus Nocardiopsis. The cultural and physiological characteristics of the strain are shown in Table 1. In

Plate 1. Scanning electron micrographs of the spores of strains C-71425 (A) and C-71799 (B).

The organisms were cultured on ISP-2 agar for 1 week at $28^{\circ} \mathrm{C}$ (bar, $1 \mu \mathrm{m}$ ).

(A)

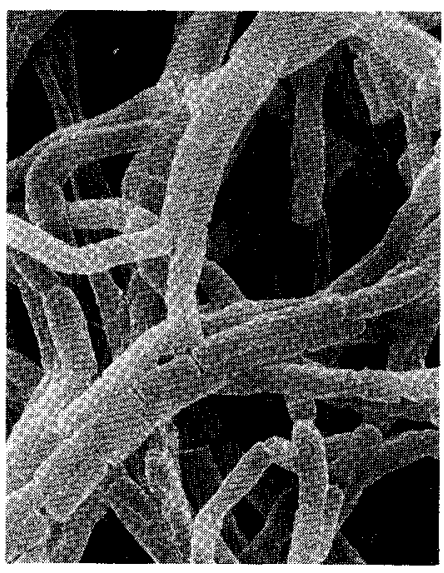

(B)

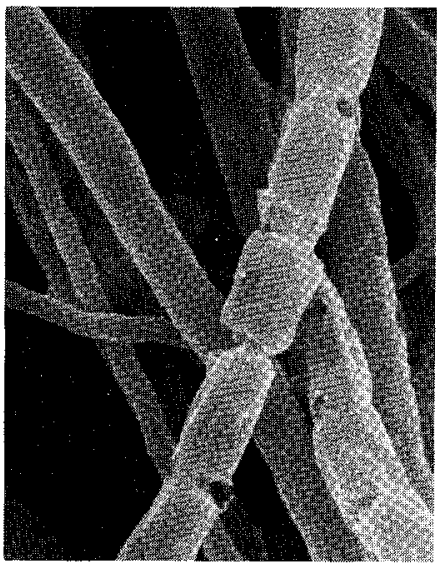


Table 1. Cultural and physiological characteristics of strains C-71425 and C-71799.

\begin{tabular}{|c|c|c|}
\hline & C-71425 & $\mathrm{C}-71799$ \\
\hline \multicolumn{3}{|l|}{ Cultural characteristics } \\
\hline \multirow{3}{*}{$\begin{array}{l}\text { Yeast extract - malt extract agar } \\
\text { (ISP-2) }\end{array}$} & G: Good, 2ea (Lt wheat) & Good, 3ie (camel) \\
\hline & A : Moderate, white & Good, white \\
\hline & $P:$ None & Light brown \\
\hline \multirow[t]{3}{*}{ Oatmeal agar (ISP-3) } & $\mathrm{G}$ : Good, 2ca (Lt ivory) & Good, 2ca (Lt ivory) \\
\hline & A: Moderate, white & Abundant, white \\
\hline & $\mathrm{P}:$ None & None \\
\hline \multirow[t]{3}{*}{ Inorganic sálts - starch agar (ISP-4) } & G: Good, 2ga (maize) & Good, 2ca (Lt ivory) \\
\hline & A: Moderate, white & Abundant, white \\
\hline & P: None & None \\
\hline \multirow[t]{3}{*}{ Glycerol - asparagine agar (ISP-5) } & G: Good, 2ga (maize) & Good, 2ig (olive gray) \\
\hline & A: Moderate, white & Abundant, $13 \mathrm{dc}$ (peal gray) \\
\hline & P : None & None \\
\hline \multirow{3}{*}{$\begin{array}{l}\text { Peptone- yeast extract - iron agar } \\
\quad \text { (ISP-6) }\end{array}$} & G: Good, 2ic (honey gold) & Poor, 2gc (bamboo) \\
\hline & A : Poor & None \\
\hline & $P:$ None & None \\
\hline \multirow[t]{3}{*}{ Tyrosine agar (ISP-7) } & G: Good, 2ea (Lt wheat) & Good, 2ie (brown) \\
\hline & A : Moderate, white & Abundant, white \\
\hline & $P:$ None & None \\
\hline \multicolumn{3}{|l|}{ Physiological characteristics } \\
\hline Temperature range for growth & $7 \sim 34^{\circ} \mathrm{C}$ & $13 \sim 42^{\circ} \mathrm{C}$ \\
\hline Nitrate reduction & + & + \\
\hline Starch hydrolysis & + & + \\
\hline Milk peptonization & + & + \\
\hline Milk coagulation & - & - \\
\hline Gelatin liquefaction & - & - \\
\hline \multicolumn{3}{|l|}{ Utilization of carbon sources } \\
\hline Positive & $\begin{array}{l}\text { Inositol, mannitol, } \\
\text { xylose, arabinose, } \\
\text { glucose, fructose, } \\
\text { rhamnose, sucrose, } \\
\text { raffinose }\end{array}$ & $\begin{array}{l}\text { Inositol, mannitol, } \\
\text { xylose }^{\mathrm{a}} \text {, arabinose } \\
\text { glucose }^{\mathrm{a}} \text {, rhamnose } \\
\text { sucrose, raffinose }^{\mathrm{a}}\end{array}$ \\
\hline Negative & Cellulose & Fructose, cellulose \\
\hline
\end{tabular}

a Weakly positive.

G: Growth, A: aerial mass color, P: soluble pigment.

comparison with known species in the genus Nocardiopsis, strain C-71425 has characteristics similar to $N$. dassonville ${ }^{16)}$ and is thought to be the same species. Therefore, the strain is designated $N$. dassonvillei C-71425.

Strain C-71799 was isolated from a soil sample collected in Okinawa Prefecture, Japan. Cell analysis of the strain showed the presence of LL-diaminopimelic acid, and it was classified as chemotype I/NC. The strain forms straight and flexuous mycelia and forms spore chains which consist of about 20 spores each. The spores are cylindrical and have a smooth surface (Plate 1B). The color of the mature sporulated aerial mycelium is in the Gray series. These characteristics of strain C-71799 indicate that it belongs to the genus Streptomyces. The cultural and physiological characteristics of strain C-71799 are shown in Table 1. Further studies are needed to determine the taxonomical niche of strain C-71799.

\section{Production and Isolation}

TAN-999 was produced by cultivating strain C-71425. The amount of TAN-999 in the culture at 90 hours reached about $50 \mu \mathrm{g} / \mathrm{ml}$. TAN-1030A was produced by cultivating strain C-71799, and the amount of the metabolite reached a maximum $(15 \mu \mathrm{g} / \mathrm{ml})$ at about 140 hours. Staurosporine was also produced 
Table 2. Physico-chemical properties of TAN-999 and TAN-1030A.

\begin{tabular}{|c|c|c|}
\hline Property & TAN-999 & TAN-1030A \\
\hline Appearance & Pale yellow crystals & Colorless crystals \\
\hline $\mathrm{MP}\left({ }^{\circ} \mathrm{C}, \mathrm{dec}\right)$ & 221 & $290 \sim 295$ \\
\hline$[\alpha]_{\mathrm{D}}^{24}(c 0.5, \mathrm{DMF})$ & $+42^{\circ}$ & $0^{\circ}$ \\
\hline $\mathrm{MS}(\mathrm{m} / \mathrm{z})$ & $496^{\mathrm{a}} \mathrm{M}^{+}$ & $467^{b}(M+H)^{+}$ \\
\hline Molecular formula & $\mathrm{C}_{29} \mathrm{H}_{28} \mathrm{~N}_{4} \mathrm{O}_{4}\left(\frac{1}{2} \mathrm{H}_{2} \mathrm{O}\right)$ & $\mathrm{C}_{27} \mathrm{H}_{22} \mathrm{~N}_{4} \mathrm{O}_{4}\left(\mathrm{H}_{2} \mathrm{O}\right)$ \\
\hline Anal & Calcd Found & Calcd Found \\
\hline $\mathrm{C}$ & $68.90, \quad 68.59$ & $66.93, \quad 67.23$ \\
\hline $\mathrm{H}$ & $5.78, \quad 5.64$ & $4.99, \quad 5.07$ \\
\hline $\mathrm{N}$ & $11.08, \quad 10.86$ & $11.56, \quad 11.70$ \\
\hline $\mathrm{UV} \lambda_{\max }^{\mathrm{MeOH}} \mathrm{nm}(\varepsilon)$ & $\begin{array}{l}245(31,200), 296(60,300), 341(19,500) \\
352(\mathrm{sh}, 16,200), 368(11,000)\end{array}$ & $\begin{array}{l}233(29,400), 244(\mathrm{sh}, 28,000) \\
263(\mathrm{sh}, 31,300), 275(\mathrm{sh}, 42,000) \\
289(71,000), 319(\mathrm{sh}, 13,400), 333(17,700) \\
352(12,100), 369(13,400)\end{array}$ \\
\hline IR $v_{\max }(\mathrm{KBr}) \mathrm{cm}^{-1}$ & $\begin{array}{l}3430,2950,1680,1590,1460,1420 \\
1360,1320,1290,1260,1210,1120 \\
1040,840,800,760\end{array}$ & $\begin{array}{l}3430,3160,2940,2860,1680,1590,1460 \\
1400,1350,1320,1290,1260,1230,1120 \\
1020,950,920,840,820,780,740\end{array}$ \\
\hline \multicolumn{3}{|l|}{ Color reaction } \\
\hline Positive & $\begin{array}{l}\text { Ninhydrin, Barton; Ehrlich, } \\
\text { Dragendorff }\end{array}$ & Barton, Ehrlich \\
\hline Negative & $\mathrm{FeCl}_{3}$ & Ninhydrin, Dragendorff \\
\hline
\end{tabular}

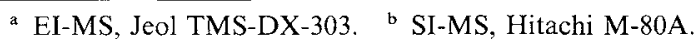

Table 3. Mobilities of TAN-999, TAN-1030A and staurosporine on TLC and HPLC.

\begin{tabular}{|c|c|c|c|}
\hline Mobilities & TAN-999 & TAN-1030A & Staurosporine \\
\hline Rf value of TLC & 0.11 & 0.61 & 0.11 \\
\hline$(2)$ & 0.20 & 0.14 & 0.20 \\
\hline Retention time of HPLC (minutes) ${ }^{\mathrm{b}}$ & 6.0 & 4.7 & 6.3 \\
\hline
\end{tabular}

a Adsorbent: Kieselgel $60 \mathrm{~F}_{254}$ (E. Merck AG.). Solvent system: (1) EtOAc-MeOH (96:4), (2) $\mathrm{CHCl}_{3}-\mathrm{MeOH}$ (96:4). Detection: UV lamp at $254 \mathrm{~nm}$.

b Equipment: Model 6000A/660/440 (Waters assoc.). Column: ODS, YMC-Pack A-312 (Yamamura Chem. Lab.). Mobile phase: $55 \% \mathrm{CH}_{3} \mathrm{CN}-0.01 \mathrm{M}$ phosphate buffer (pH 6.3). Detection: UV absorbance at $254 \mathrm{~nm}$. Flow rate: $2 \mathrm{ml} / \mathrm{minute}$.

by this strain.

TAN-999 (1) and TAN-1030A (2) are fat-soluble compounds. Therefore, purification was carried out by extraction with EtOAc, column chromatography using silica gel and crystallization. The active fractions were detected by morphological changes in Mm 1 cells and TLC. The physico-chemical properties and mobilities of $\mathbf{1}$ and $\mathbf{2}$ are summarized in Tables 2 and 3. The molecular formulae of $\mathbf{1}$ and $\mathbf{2}$ were determined on the basis of the elemental analyses, the molecular ion peaks in the mass spectra and the carbon numbers in the ${ }^{13} \mathrm{C}$ NMR spectra. The UV absorption spectra suggested $\mathbf{1}$ and $\mathbf{2}$ have a chromophore similar to the indolocarbazole moiety in staurosporine.

\section{Structural Elucidation}

${ }^{1} \mathrm{H}$ and ${ }^{13} \mathrm{C}$ NMR data are summarized in Tables 4 and 5 . The signals were assigned based on $2 \mathrm{D}$ NMR experiments, such as ${ }^{1} \mathrm{H}-{ }^{1} \mathrm{H}$ correlation spectroscopy (COSY), ${ }^{1} \mathrm{H}-{ }^{13} \mathrm{C}$ COSY, long range ${ }^{1} \mathrm{H}-{ }^{13} \mathrm{C}$ COSY (Fig. 2) and nuclear Overhauser and exchange spectroscopy (NOESY). When the ${ }^{1} \mathrm{H}$ NMR spectrum of 1 was compared with that of staurosporine, an aromatic proton found in staurosporine was lacking and a methoxy signal at $3.95 \mathrm{ppm}$ was observed in 1 . A long range coupling was found between the methoxy protons and C-10 (Fig. 3). Further observation of NOE between the methoxy protons and 9-H 
Table 4. ${ }^{1} \mathrm{H}$ NMR spectral data of TAN-999 and TAN-1030A $(300 \mathrm{MHz}){ }^{a}$

\begin{tabular}{|c|c|c|c|}
\hline Position & TAN-999b & TAN-1030A & Staurosporine ${ }^{c}$ \\
\hline 1 & $7.27(\mathrm{~d}, J=8.0)$ & $7.70(\mathrm{~d}, J=8.2)$ & $7.56(\mathrm{~d}, J=8.1)$ \\
\hline 2 & $7.46(\mathrm{t})$ & $7.50(\mathrm{t})$ & $7.45(t)$ \\
\hline 3 & $7.35(\mathrm{t})$ & $7.32^{\mathrm{d}}(\mathrm{t})$ & $7.27^{\mathrm{d}}(\mathrm{t})$ \\
\hline 4 & $9.40(\mathrm{~d}, J=7.8)$ & $9.31(\mathrm{~d}, J=7.8)$ & $9.30(\mathrm{~d}, J=7.9)$ \\
\hline 6 & $6.28(\mathrm{~s})$ & $8.58(\mathrm{~s})$ & $8.53(\mathrm{~s})$ \\
\hline 7 & $4.96(\mathrm{ABq}, J=17.0)$ & 4.96 (s like) & 4.96 (s like) \\
\hline 8 & $7.75(\mathrm{~d}, J=8.5)$ & $7.98(\mathrm{~d}, J=8.0)$ & $7.96(\mathrm{~d}, J=7.3)$ \\
\hline 9 & $6.96(\mathrm{dd}, J=2.0,8.5)$ & $7.32^{\mathrm{d}}(\mathrm{t})$ & $7.27^{\mathrm{d}}(\mathrm{t})$ \\
\hline 10 & & $7.44(\mathrm{t})$ & $7.41(t)$ \\
\hline 11 & $7.46(\mathrm{~d}, J=2.0)$ & $8.01(\mathrm{~d}, J=9.1)$ & $7.98(\mathrm{~d}, J=8.4)$ \\
\hline $1^{\prime}$ & $6.53(\mathrm{~d}, J=5.6)$ & $7.04(\mathrm{~d}, J=5.2)$ & 6.68 (s like) \\
\hline \multirow[t]{2}{*}{$2^{\prime}$} & $2.38(\mathrm{~m})$ & $3.01(\mathrm{dd}, J=5.2,14.0)$ & $2.49(\mathrm{~m})$ \\
\hline & $2.75(\mathrm{dd}, J=4.0,14.7)$ & $3.63(\mathrm{~d}, J=14.0)$ & \\
\hline $3^{\prime}$ & $3.35(\mathrm{~m})$ & & $3.24(\mathrm{~m})$ \\
\hline $4^{\prime}$ & $3.87(\mathrm{~d}, J=3.5)$ & $4.73(\mathrm{~s})$ & $4.04(\mathrm{~d}, J=3.2)$ \\
\hline $6^{\prime}$ & $2.33(\mathrm{~s})$ & $2.47(\mathrm{~s})$ & $2.29(\mathrm{~s})$ \\
\hline $3^{\prime}-\mathrm{NCH}_{3}$ & $1.57(\mathrm{~s})$ & & $1.44(\mathrm{~s})$ \\
\hline $4^{\prime}-\mathrm{OCH}_{3}$ & $3.44(\mathrm{~s})$ & $3.43(\mathrm{~s})$ & $3.32(\mathrm{~s})$ \\
\hline $10-\mathrm{OCH}_{3}$ & $3.95(\mathrm{~s})$ & & \\
\hline $3-\mathrm{NOH}$ & & $10.45(\mathrm{~s})$ & \\
\hline
\end{tabular}

a The $\delta$ values were recorded in ppm downfield from TMS using a Brucker AC-300. Coupling constants in $\mathrm{Hz}$ are given in parentheses. ${ }^{b}$ In $\mathrm{CDCl}_{3} .{ }^{\mathrm{c}}$ In DMSO- $d_{6},{ }^{\mathrm{d}}$ These signals overlapped.

Table 5. ${ }^{13} \mathrm{C}$ NMR spectral data of TAN-999 and TAN-1030A $(75 \mathrm{MHz}){ }^{\mathrm{a}}$

\begin{tabular}{cccc|cccc}
\hline Position & TAN-999 $^{\mathrm{b}}$ & TAN-1030A $^{\mathrm{c}}$ & Staurosporine $^{\mathrm{c}}$ & Position $^{2}$ & TAN-999 $^{\mathrm{b}}$ & TAN-1030A $^{\mathrm{c}}$ & Staurosporine $^{\mathrm{c}}$ \\
\hline 1 & $106.89 \mathrm{~d}$ & $108.88 \mathrm{~d}$ & $108.18 \mathrm{~d}$ & 11 & $100.72 \mathrm{~d}$ & $115.58 \mathrm{~d}$ & $115.12 \mathrm{~d}$ \\
2 & $124.88 \mathrm{~d}$ & $125.21 \mathrm{~d}$ & $124.76 \mathrm{~d}$ & $11 \mathrm{a}$ & $141.04 \mathrm{~s}$ & $139.82 \mathrm{~s}$ & $139.34 \mathrm{~s}$ \\
3 & $119.65 \mathrm{~d}$ & $119.52 \mathrm{~d}$ & $118.88 \mathrm{~d}$ & $12 \mathrm{a}$ & $130.63 \mathrm{~s}$ & $128.03 \mathrm{~s}$ & $129.90 \mathrm{~s}$ \\
4 & $126.50 \mathrm{~d}$ & $125.61 \mathrm{~d}$ & $125.51 \mathrm{~d}$ & $12 \mathrm{~b}$ & $127.09 \mathrm{~s}$ & $124.60 \mathrm{~s}$ & $126.59 \mathrm{~s}$ \\
$4 \mathrm{a}$ & $123.55 \mathrm{~s}$ & $122.85 \mathrm{~s}$ & $122.42 \mathrm{~s}$ & $13 \mathrm{a}$ & $136.67 \mathrm{~s}$ & $136.01 \mathrm{~s}$ & $136.25 \mathrm{~s}$ \\
$4 \mathrm{~b}$ & $114.88 \mathrm{~s}$ & $114.98 \mathrm{~s}$ & $114.02 \mathrm{~s}$ & $1^{\prime}$ & $80.12 \mathrm{~d}$ & $82.17 \mathrm{~d}$ & $79.82 \mathrm{~d}$ \\
$4 \mathrm{c}$ & $118.58 \mathrm{~s}$ & $119.15 \mathrm{~s}$ & $118.71 \mathrm{~s}$ & $2^{\prime}$ & $30.29 \mathrm{t}$ & $29.71 \mathrm{t}$ & $29.27 \mathrm{t}$ \\
5 & $173.81 \mathrm{~s}$ & $171.77 \mathrm{~s}$ & $172.18 \mathrm{~s}$ & $3^{\prime}$ & $50.36 \mathrm{~d}$ & $145.12 \mathrm{~s}$ & $49.98 \mathrm{~d}$ \\
7 & $45.92 \mathrm{t}$ & $45.30 \mathrm{t}$ & $45.33 \mathrm{t}$ & $4^{\prime}$ & $84.26 \mathrm{~d}$ & $83.57 \mathrm{~d}$ & $82.70 \mathrm{~d}$ \\
$7 \mathrm{a}$ & $131.48 \mathrm{~s}$ & $132.25 \mathrm{~s}$ & $131.91 \mathrm{~s}$ & $5^{\prime}$ & $91.06 \mathrm{~s}$ & $96.16 \mathrm{~s}$ & $91.00 \mathrm{~s}$ \\
$7 \mathrm{~b}$ & $114.24 \mathrm{~s}$ & $114.02 \mathrm{~s}$ & $113.38 \mathrm{~s}$ & $6^{\prime}$ & $29.69 \mathrm{q}$ & $28.59 \mathrm{q}$ & $29.63 \mathrm{q}$ \\
$7 \mathrm{c}$ & $118.92 \mathrm{~s}$ & $123.79 \mathrm{~s}$ & $123.79 \mathrm{~s}$ & $3^{\prime}-\mathrm{NCH}_{3}$ & $33.38 \mathrm{q}$ & & $33.19 \mathrm{q}$ \\
8 & $120.94 \mathrm{~d}$ & $120.72 \mathrm{~d}$ & $120.70 \mathrm{~d}$ & $4^{\prime}-\mathrm{OCH}_{3}$ & $57.24 \mathrm{q}$ & $58.29 \mathrm{q}$ & $57.14 \mathrm{q}$ \\
9 & $107.94 \mathrm{~d}$ & $120.13 \mathrm{~d}$ & $119.63 \mathrm{~d}$ & $10-\mathrm{OCH}_{3}$ & $55.78 \mathrm{q}$ & & \\
10 & $157.49 \mathrm{~s}$ & $124.64 \mathrm{~d}$ & $124.19 \mathrm{~d}$ & & & & \\
\hline
\end{tabular}

${ }^{a}$ The $\delta$ values were recorded in ppm downfield from TMS using a Brucker AC-300. ${ }^{\mathrm{b}}$ In $\mathrm{CDCl}_{3} .{ }^{\mathrm{c}}$ In $\mathrm{DMSO}-d_{6}$.

or 11-H (Fig. 3) indicated that the methoxy group is bound to the 10-position. Thus 1 was determined to be 10-methoxy staurosporine.

The difference in 2 and staurosporine was found at the $3^{\prime}$-position. Comparing the ${ }^{13} \mathrm{C}$ NMR spectra, a methine signal at $49.98 \mathrm{ppm}$ in staurosporine collapsed to a quaternary carbon at $145.12 \mathrm{ppm}$ in 2 . In addition the $N$-methyl signal at $33.19 \mathrm{ppm}$ found in staurosporine was absent. In the ${ }^{1} \mathrm{H} N \mathrm{NR}$ spectra, instead of the $N$-methyl signal at 1.44 ppm observed in staurosporine a proton signal exchangeable with $\mathrm{D}_{2} \mathrm{O}$ was observed at $10.45 \mathrm{ppm}$ in 2 . A long range coupling was found between the $\mathrm{D}_{2} \mathrm{O}$ exchangeable proton and C-3' (Fig. 3). These data suggested 2 has an oxime function at the 3'-position. Upon hydrogenation using Pt-black, compound $\mathbf{2}$ gave an amino derivative (3) which was acetylated with 
Fig. 2. Long range ${ }^{1} \mathrm{H}^{-13} \mathrm{C} \mathrm{COSY}$ spectrum of TAN-999 $\left(\mathrm{CDCl}_{3}\right)$.

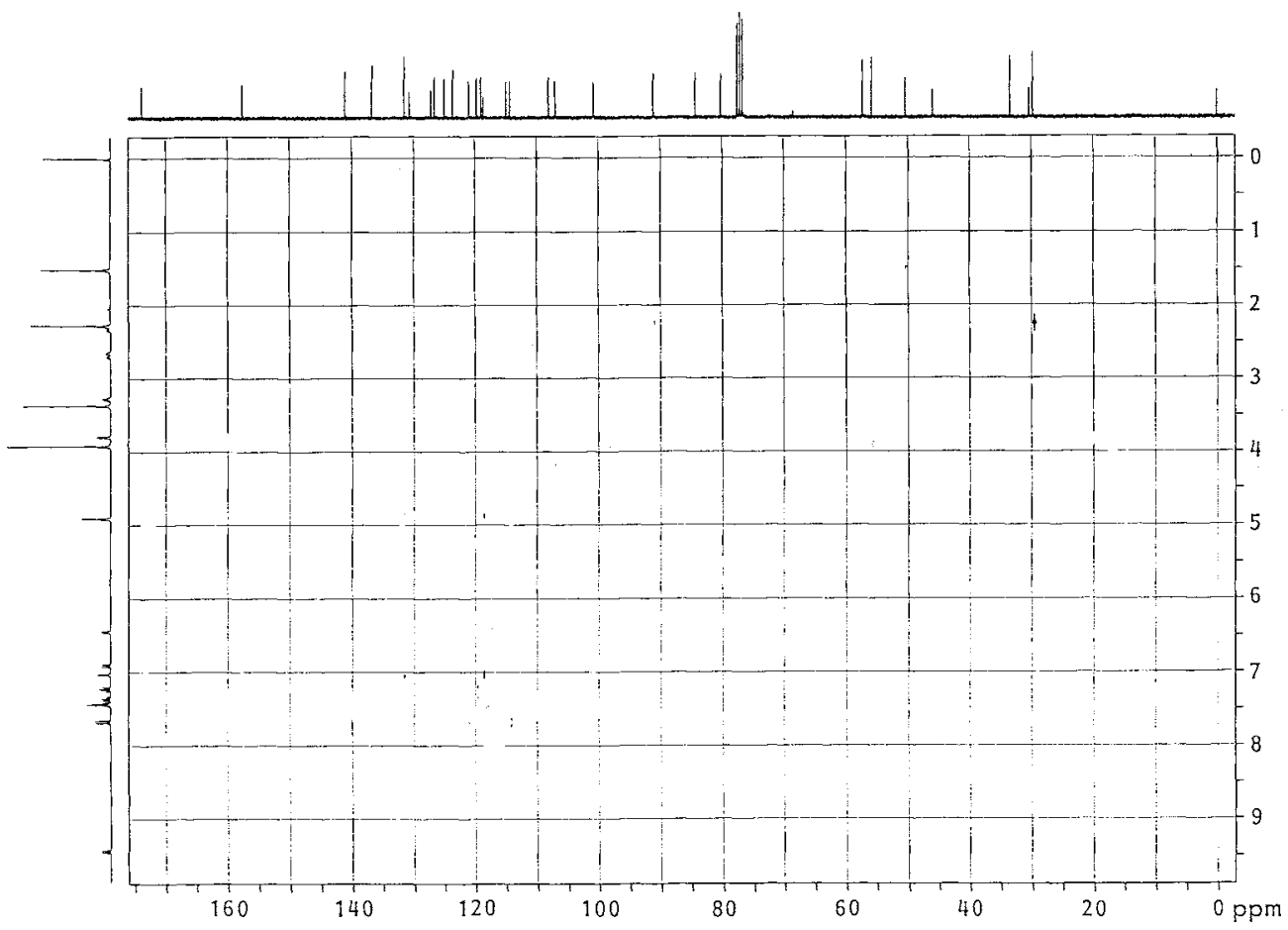

Fig. 3. Long range ${ }^{1} \mathrm{H}^{13} \mathrm{C}$ COSY and NOESY experiments of TAN-999(1) and TAN-1030A(2).

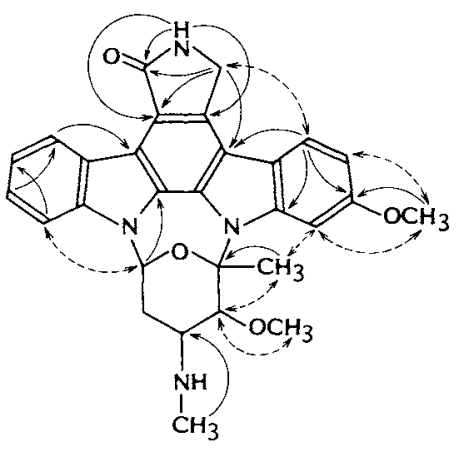

1

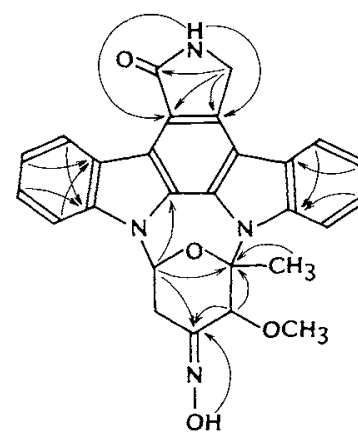

2

$\longrightarrow{ }^{1} \mathrm{H} \rightarrow{ }^{13} \mathrm{C}$ long range coupling $(\mathbf{1}: J=4.2 \mathrm{~Hz}, 2: J=12 \mathrm{~Hz})$

$\leftrightarrow-\rightarrow$ NOE

$\mathrm{Ac}_{2} \mathrm{O}$ - pyridine to compound 4 (Fig. 4). These chemical reactions confirmed the presence of an oxime function in 2. Thus the chemical structure of $\mathbf{2}$ was determined as shown in Fig. 1.

\section{Biological Activity}

TAN-999 induced spreading of Mm 1 cells. When TAN-999 was added to a culture of Mm 1 at the concentrations of 1.3 to $78 \mathrm{ng} / \mathrm{ml}$, more than $50 \%$ of the cells drastically elongated. In the control culture without the metabolite, less than $5 \%$ of the cells elongated. TAN-1030A also induced spreading of $\mathrm{Mm} 1$ cells at concentrations of 78 to $625 \mathrm{ng} / \mathrm{ml}$ (Fig. 5). The elongated cells, like activated macrophages, formed 
Plate 2. Scanning electron micrographs of Mm 1 cells.

(A) Drug free, (B) TAN-999 at $2 \mathrm{ng} / \mathrm{ml}$, (C) magnification of (B). Mm 1 cells were cultured with the metabolite for 2 days at $37^{\circ} \mathrm{C}$ (bar, $2 \mu \mathrm{m}$ ).

(A)

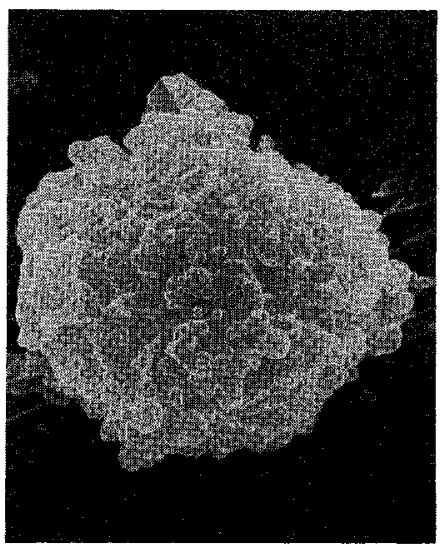

(B)

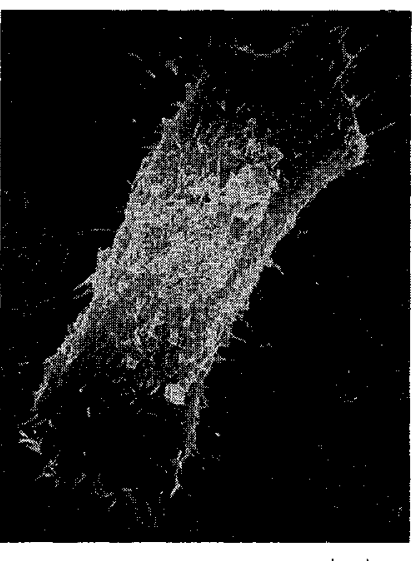

(C)

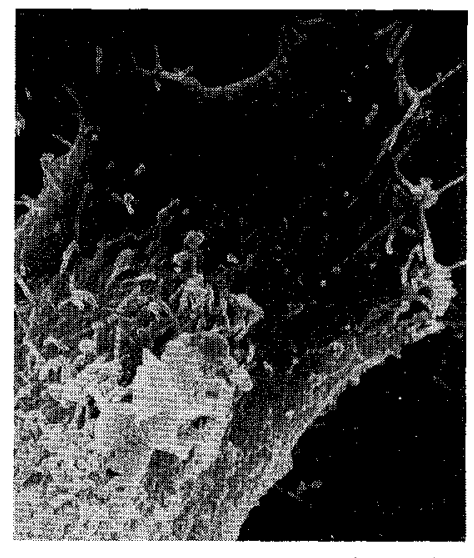

Fig. 4. Chemical reactions of TAN-1030A (2).

2

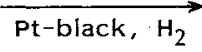<smiles>COC1C(N)CC2OC1(C)n1c3ccccc3c3c4c(c5c6ccccc6n2c5c31)C(=O)NC4</smiles>

$\mathrm{Ac}_{2} \mathrm{O}-$ pyridine<smiles>COC1C(N=C(C)C)CC2OC1(C)n1c3ccccc3c3c4c(c5c6ccccc6n2c5c31)C(=O)NC4</smiles>

4 thin lamellipodia and numerous microvilli and were clearly different from most of the cells in the control culture having a round shape with many blebs (Plate 2). Staurosporine induced spreading of the cells at 1.3 to $39 \mathrm{ng} / \mathrm{ml}$, but it was more toxic to $\mathrm{Mm} 1$ than TAN-999. In addition, compounds 3 and 4 (Fig. 4) induced similar changes in morphology of $\mathrm{Mm} 1$ at 1.3 and $50 \mathrm{ng} / \mathrm{ml}$, respectively (data not shown).

Phagocytosis of exogenous particles is an essential function of macrophages. To clarify the effect of these metabolites on the phagocytic activity of macrophages, further studies using murine macrophage cell lines were carried out. When TAN-999 at $5 \mathrm{ng} / \mathrm{ml}$ was added to a culture of $\mathrm{Mm}$ 1 , the number of phagocytic cells ingesting latex
Fig. 5. Effect of TAN-999 and TAN-1030A on growth and morphology of $\mathrm{Mm} 1$ cells.

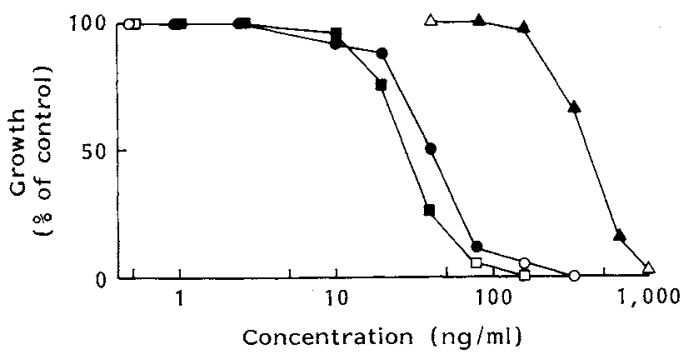

The growth of Mm I cells was evaluated by MTT assay. Changes in morphology of Mm 1 cells were determined by microscopy with an inverted light microscope. Circles, TAN-999; triangles, TAN-1030A; squares, staurosporine; closed symbols, more than $50 \%$ of $\mathrm{Mm} 1$ cells in a microscopic field elongated. 
Table 6. Effect of TAN-999 and TAN-1030A on the phagocytic activity, Fcy receptor expression and $\beta$-glucuronidase activity of murine macrophage cell lines, Mm 1 and J774A.1.

\begin{tabular}{|c|c|c|c|c|c|c|}
\hline \multirow{2}{*}{ Metabolite } & \multirow{2}{*}{$\begin{array}{c}\text { Conc } \\
(\mathrm{ng} / \mathrm{ml})\end{array}$} & \multicolumn{3}{|c|}{$\mathrm{Mm} 1$} & \multicolumn{2}{|c|}{ J774A.1 } \\
\hline & & Phago. $^{\mathrm{a}}$ & $\mathrm{FcR}^{\mathrm{b}}$ & $\beta$-Glu. ${ }^{\mathrm{c}}$ & Phago. $^{a}$ & $\mathrm{FcR}^{b}$ \\
\hline \multirow[t]{4}{*}{ TAN-999 } & 0 & 1.0 & 1.0 & 1.0 & 1.0 & 1.0 \\
\hline & 1 & 2.0 & 1.6 & 1.4 & 10.7 & 1.1 \\
\hline & 2 & 4.8 & 1.7 & 1.3 & 11.5 & 1.5 \\
\hline & 5 & 9.6 & 3.9 & 1.1 & 11.7 & 1.7 \\
\hline \multirow[t]{3}{*}{ TAN-1030A } & 50 & nd & 4.7 & 1.1 & 2.4 & 1.3 \\
\hline & 100 & nd & 3.3 & 1.3 & 4.8 & 1.3 \\
\hline & 200 & nd & 1.7 & 1.2 & 9.0 & 1.1 \\
\hline \multirow[t]{2}{*}{ Staurosporine } & 1 & 1.8 & 1.5 & 1.1 & 12.0 & 1.7 \\
\hline & 2 & 9.9 & 1.6 & 1.1 & 11.8 & 1.3 \\
\hline
\end{tabular}

$\mathrm{Mm} 1$ and $\mathrm{J} 774 \mathrm{~A} .1$ cells were cultured with these metabolites for 2 days at $37^{\circ} \mathrm{C}$ under $5 \% \mathrm{CO}_{2}$.

a Ratio of phagocytic positive cells in comparison with the control culture as 1.0. Phagocytic positive cells in the control culture of $\mathrm{Mm} 1$ and J774A.1 were 1.6 and $8.2 \%$, respectively.

b Ratio of EA-rosette positive cells in comparison with the control culture as 1.0. EA-rosette positive cells in the control culture of $\mathrm{Mm} 1$ and J774A.1 were 5.4 and $24.0 \%$, respectively.

- Ratio of $\beta$-glucuronidase activities of modulated cells in comparison with the control cells as 1.0.

nd: Not determined.

Table 7. Phagocytosis-dependent respiratory burst in mouse peritoneal macrophages incubated with TAN-999 and TAN-1030A.

\begin{tabular}{lcc}
\hline Metabolite & $\begin{array}{c}\text { Concentration } \\
(\mathrm{ng} / \mathrm{ml})\end{array}$ & $\begin{array}{c}\text { Relative } \\
\text { chemiluminescence }\end{array}$ \\
\hline TAN-999 & 0.01 & 1.27 \\
& 0.1 & 1.93 \\
TAN-1030A & 1 & 1.58 \\
& 1 & 1.74 \\
Staurosporine & 10 & 1.17 \\
& 0.01 & 1.03 \\
& 0.1 & 1.69 \\
& 1 & 1.32 \\
\end{tabular}

PECs were harvested 96 hours after administration of PP. The adherent macrophages were obtained by removing non-adherent cells from the PECs and were incubated with these metabolites for 2 days under $5 \%$ $\mathrm{CO}_{2}$. The phagocytosis-dependent respiratory burst was induced by adding opsonized zymosan and was evaluated by measuring the chemiluminescence response with luminol. Each experiment was performed in duplicate and the photon counts were averaged.

a Chemiluminescence (photon counts) for 8 minutes of the drug-free control was 14,900 .
Table 8. Phagocytosis-dependent respiratory burst in peritoneal macrophages from mice administered TAN999 and TAN-1030A.

\begin{tabular}{ccc}
\hline Metabolite & $\begin{array}{c}\text { Dose } \\
(\mu \mathrm{g} / \mathrm{kg})\end{array}$ & $\begin{array}{c}\text { Relative } \\
\text { chemiluminescence }\end{array}$ \\
\hline TAN-999 & 0.005 & 1.32 \\
& 0.05 & 1.94 \\
TAN-1030A & 0.5 & 1.08 \\
& 0.05 & 1.12 \\
Staurosporine & 0.5 & 1.59 \\
& 5 & 1.39 \\
& 0.005 & 1.37 \\
& 0.05 & 1.18 \\
& 0.5 & 1.00
\end{tabular}

Mice received these metabolites 24 hours before PECs were harvested. The respiratory burst was measured by the method described in the footnote of Table 7. Each experiment was performed in duplicate, and the photon counts were averaged.

a Chemiluminescence (photon counts) for 8 minutes of the control was 21,900 .

particles reached about 9 times that in the control culture (Table 6). A similar effect was obtained when TAN-999 was added to a culture of J774A.1, a cell line which is highly phagocytic. These results indicate that TAN-999 augments phagocytic activity of these murine macrophage cell lines. TAN-1030A and staurosporine also increased the number of phagocytic cells in these cell lines.

Since several functions of macrophages are mediated by Fcy receptors on their surfaces, the effect of these metabolites on the expression of the Fcy receptors of Mm 1 and J774A.1 was examined. TAN-999 
at a concentration of $5 \mathrm{ng} / \mathrm{ml}$ increased the EA $\gamma$-rosette formation of $\mathrm{Mm} 1$ cells to 4 times that of the control. The metabolite also significantly enhanced the rosette formation of J774A.1 (Table 6). These results indicate that TAN-999 augments the expression of Fcy receptors on the surface of the murine macrophage cell lines. TAN-1030A also enhanced the expression of Fc $\gamma$ receptors at 50 to $100 \mathrm{ng} / \mathrm{ml}$, and similar results were obtained in the presence of staurosporine at 1 to $2 \mathrm{ng} / \mathrm{ml}$.

$\beta$-Glucuronidase, a lysosomal enzyme, is an important marker for macrophage functions against bacterial infection. TAN-999 increased the activity of this enzyme. When the metabolite was added to a culture of $\mathrm{Mm} 1$ at $1 \mathrm{ng} / \mathrm{ml}$, the enzyme activity increased 1.4 times. Since the enzyme activity was normal level in the presence of TAN-999 at $5 \mathrm{ng} / \mathrm{ml}$, the metabolite at high concentrations seems to inhibit lysosome function in Mm 1 cells. A significant increase in the enzyme activity was also observed in the presence of TAN-1030A (Table 6). Staurosporine scarcely increased the enzyme activity.

Since a respiratory burst was scarcely detected in $\mathrm{Mm} \mathrm{1}$, the effects of these metabolites on the phagocytosis-dependent respiratory burst in mouse peritoneal macrophages was investigated. When PP-elicited peritoneal macrophages from C57BL/6 mice were incubated with TAN-999 or TAN-1030A, the respiratory bursts in these macrophages were enhanced. The enhancement by TAN-999 occurred at concentrations of 0.01 to $1 \mathrm{ng} / \mathrm{ml}$ and reached a maximum at $0.1 \mathrm{ng} / \mathrm{ml}$ ( 2 times higher than the drug-free control). An increase in the respiratory burst in the macrophages also occurred in the presence of TAN-1030A at concentrations of 1 to $10 \mathrm{ng} / \mathrm{ml}$ (Table 7). Similar results were obtained by adding staurosporine at 0.01 to $0.1 \mathrm{ng} / \mathrm{ml}$.

When less than $1 / 10,000$ of the lethal doses of the metabolites were injected ip 24 hours before harvesting peritoneal cells, the peritoneal macrophages showed a greatly enhanced phagocytosis-dependent respiratory burst. The increase in respiratory burst occurred with 0.005 to $0.05 \mu \mathrm{g} / \mathrm{kg}$ of TAN-999 and with 0.5 to $5 \mu \mathrm{g} / \mathrm{kg}$ of TAN-1030A (Table 8). These results indicate that these metabolites modulate macrophages to an activated state in mice. Peritoneal macrophages from staurosporine treated mice showed an increase in respiratory burst only at $0.05 \mu \mathrm{g} / \mathrm{kg}$.

\section{Discussion}

Due to their phagocytic function and their ability to secrete certain effector molecules, macrophages contribute to the host's ability to protect itself against invasion by microorganisms and against development of tumors. Our present results show that TAN-999 and TAN-1030A enhance non-specific phagocytic activity and the expression of $\mathrm{Fc} \gamma$ receptors in murine macrophage cell lines. These metabolites also increase lysosomal enzyme activity in these cells. Moreover, phagocytosis-dependent respiratory burst in mouse peritoneal macrophages was stimulated by TAN-999 and TAN-1030A in vitro and in vivo. These findings imply that these microbial metabolites may augment macrophage functions in animal and human bodies, resulting in the potentiation of defense mechanisms against infection and tumor development in these hosts. In preliminary experiments, the growth of B16 melanoma in syngeneic C57BL/6 mice was inhibited by ip pretreatment with TAN-999 (data not shown).

Staurosporine is a potent inhibitor of protein kinases, ${ }^{17,18)}$ especially protein kinase C. TAN-999 also inhibits protein kinase C (Dr. KozAI of our Central Research Division; unpublished data). Moreover, we found that genistein, an inhibitor of tyrosine kinase ${ }^{19,20)}$ induced spreading of Mm 1 cells and enhanced the respiratory burst in mouse peritoneal macrophages. These facts suggest that the activation of macrophages is regulated by protein kinases. Specific inhibitors of protein kinases are expected to act as macrophage activators which could protect against tumor development and microbial infection. 


\section{Acknowledgments}

We thank Dr. T. HASEGAWA, Institute for Fermentation, Osaka, for his valuable advice on the taxonomical studies. We also thank Drs. Y. SUGINO, Y. NAKAO and H. OKAZAKI for their continuing interest and encouragement. Thanks are also due to Messrs T. NaKAyama and K. Koyama for their skillful assistance.

\section{References}

1) WALKeR, W. S. \& R. B. HeSTER: The functional heterogeneity of macrophages. In The Reticuloendothelial System. A Comprehensive Treaties. Vol. 6. Ed., J. A. Bellanti et al., pp. $27 \sim 42$, Plenum Press, 1984

2) FIDLER, I. J. \& A. J. SchroIT: Recognition and destruction of neoplastic cells by activated macrophages: discrimination of altered self. Biochim. Biophys. Acta 948: 151 173, 1988

3) Ōmura, S.; Y. Iwal, A. Hirano, A. Nakagawa, J. Awaya, H. Tsuchiya, Y. Takahashi \& R. Masuma: A new alkaloid AM-2282 of Streptomyces origin. Taxonomy, fermentation, isolation and preliminary characterization. J. Antibiotics 30: 275 282, 1977

4) Furusaki, A.; N. Hashiba \& T. Matsumoto: X-Ray crystal structure of staurosporine: A new alkaloid from Streptomyces strain. J. Chem. Soc. Chem. Commun. 1978: 800 801, 1978

5) Shirling, E. B. \& D. Gottlieb: Methods for characterization of Streptomyces species. Int. J. Syst. Bacteriol. 16: $313 \sim 340,1966$

6) JaCobson, E.; W. C. Grauville \& C. E. Fogs (Ed.): Color Harmony Manual. 4th Ed. Container Corporation of America, 1958

7) Hasegawa, T.; M. Takizawa \& S. TANida: A rapid analysis for chemical grouping of aerobic actinomycetes. J. Gen. Appl. Microbiol. 29: 319 322, 1983

8) Tanida, S.; T. Hasegawa, M. Murol \& E. Higashide: Dnacins, new antibiotics. I. Producing organism, fermentation, and antimicrobial activities. J. Antibiotics 33: 1443 1448, 1980

9) Kyoizumi, S.; K. Teshigawara, S. Sakaguchi \& T. Masuda: A cloned cell line, Mk 1, possessing Ia antigens and accessory cell activity. J. Immunol. 128: 2586 2594, 1982

10) Kitano, K.; Y. Shintani, Y. Ichimori, K. Tsukamoto, S. Sasai \& M. Kida: Production of human monoclonal antibodies by heterohybridomas. Appl. Microbiol. Biotechnol. 24: 282 286, 1986

11) RALPH, P. \& I. NAKOINZ: Direct toxic effects of immunopotentiators on monocytic, myelomonocytic, and histocytic or macrophage tumor cells in culture. Cancer Res. 37: 546 550, 1977

12) RaLPH, P. \& I. NAKoINZ: Antibody-dependent killing of erythrocyte and tumor targets by macrophage-related cell lines: Enhancement by PPD and LPS. J. Immunol. 119: 950 954, 1977

13) Tada, H.; O. Shiho, K. Kuroshima, M. Koyama \& K. Tsukamoto: An improved colorimetric assay for interleukin 2. J. Immunol. Methods 93: 157 165, 1985

14) Kerbel, R. S. \& B. E. Elliott: Detection of Fc receptors. Methods in Enzymol. 93: 113 147, 1983

15) WREGHT, D. C. \& S. E. Malaivesta: The mobilization and extracellular release of granular enzymes from human leukocytes during phagocytosis. J. Cell Biol. 53: 788 797, 1972

16) MeYer, J.: Nocardiopsis, a new genus of the order Actinomycetales. Int. J. Syst. Bacteriol. 26: 487 493, 1976

17) Tamaoki, T.; H. Nomoto, I. Takahashi, Y. Kato, M. Morimoto \& F. Tomita: Staurosporine, a potent inhibitor of phospholipid/Ca ${ }^{++}$dependent protein kinase. Biochem. Biophys. Res. Commun. 135: 397 402, 1986

18) Nakano, H.; E. Kobayashi, I. Takahashi, T. Tamaoki, Y. KuZUU \& H. Iba: Staurosporine inhibits tyrosine-specific protein kinase activity of Rous sarcoma virus transforming protein p60. J. Antibiotics 40: 706 708, 1987

19) Ogawara, H.; T. Akiyama, J. Ishida, S. Watanabe \& K. Suzuki: A specific inhibitor for tyrosine protein kinase from Pseudomonas. J. Antibiotics 39: 606 608, 1986

20) Akiyama, T.; J. Ishida, S. Nakagawa, H. Ogawara, S. Watanabe, N. Itoh, M. Shibuya \& Y. Fukami: Genistein, a specific inhibitor of tyrosine-specific protein kinases. J. Biol. Chem. 262: 5592 5595, 1987 